\title{
Decentralisation and the Living Conditions and Struggle of Fishers: A Study in West Java and East Kalimantan
}

\author{
Rilus A. Kinseng ${ }^{1}$ \\ ${ }^{1}$ Senior lecturer at the Department of Communication and Community Development Sciences, Faculty of \\ Human Ecology, Bogor Agricultural University, Indonesia \\ Correspondance: Rilus A. Kinseng, Department of Communication and Community Development Sciences, \\ Faculty of Human Ecology, Bogor Agricultural University, Indonesia. E-mail: rilus_kinseng@hotmail.com; \\ rilus.kinseng@gmail.com
}

Received: November 17, 2016

doi:10.5539/jsd.v10n2p71

\author{
Accepted: March 7, 2017 Online Published: March 30, 2017 \\ URL: https://doi.org/10.5539/jsd.v10n2p71
}

\begin{abstract}
Some argue that one of the key factors contributing to marine resource and environmental degradation, as well as to the poverty of fishers in Indonesia was the centralized resource management system. Since the start of the era of reform in 1998, Indonesia has experienced many fundamental changes, including decentralization of fisheries management.

This paper assess impacts of the decentraization on fishers living condition and their struggle. This study shows that decentralization in Indonesia, including decentralization of fishery resources management, has not brought any significant improvement to fishers' living conditions. Thus, I argue that what is important is not the decentralization per se, but those who are in power. If the people in power put more emphasize in pursuing economic growth and their own prosperity without paying enough attention to the environment and poor people, decentralization would not bring any significant improvement to the environment and poor people such as fishers. In that case, decentarlization simply moves the locus of power from central government to local government.
\end{abstract}

Keywords: decentralization, fisheries management, Indonesia, poverty, social movement

\section{Introduction}

Indonesia consists of more than 17,500 islands, making it the largest archipelagic nation in the world. Located between the Pacific and Indian oceans, and with two-thirds of its territory is sea, this maritime nation is blessed with a "mega diversity" of marine life (Dewan Hankamnas and BPP Teknologi, 1996). Because of these natural characteristics, the livelihoods of many Indonesian people are closely related to marine resources. Among them are fishers. The Indonesian Ministry of Marine Affairs and Fisheries (MMAF) estimated that there were around 2,255,650 fishers in Indonesia in 2009 (MMAF, 2009) (Note 1).

Most Indonesian fishers fall into the small-scale category. The Minister of Marine Affairs and Fisheries (2010) stated that $94 \%$ of fishing boats in Indonesia are under five gross tonnages. In fact, in 2009, 205,460 out of 596,230 fishing boats (34.5\%) were "non-powered boats". In other words, most of Indonesian fishers today are small-scale fishers. Thus, the picture of Indonesian fishers today has not changed significantly from more than twenty years ago. Bailey (1988), for example, noted that most Indonesian fishers were small-scale or "artisanal": "...most fishers are small-scale producers who are among the poorest of the poor in Indonesian society" (Bailey, 1988:25). Echoing Bailey, Betke also described the majority of Indonesian fishers as 'traditional' (Betke, 1988:53).

Some argue that one of the key factors contributing to marine resource and environmental degradation, as well as to the poverty of fishers during the New Order was the centralized resource management system that Soeharto implemented. Rokhmin Dahuri, the Minister of Marine Affairs and Fisheries under Megawati (1999 to 2004), for example, said that "With centralized development in the past, many problems emerged, including destruction of marine and coastal resources and marginalization of local actors" (Dahuri in Satria et.al, 2002). He added that it is "...very difficult to find empirical evidence of any nation that has succeeded in managing its fisheries resources in a centralized manner." Satria and Matsuda (2004a) agree that centralized management of marine fisheries has caused resource depletion. 
For those who argue that centralization is a root cause of marine and fishery degradation and destruction as well as fishers' poverty, decentralization is a key to addressing these problems. To quote Dahuri again: "It has been proven that decentralization of fisheries resource management is the right step and therefore needs to become an entry point for sustainable fisheries resource management" (Dahuri in Satria et.al, 2002). Friedmann presents a similar argument and states that: "It is an empirically verifiable phenomenon that people wish to protect the environment on which they depend for their life and livelihood" (Friedmann, 1998:81). Similarly, Satria and Matsuda (2004a) argued that, "...decentralization is the most appropriate form of fisheries management, enabling local governments to fundamentally control local fishing through a community-based management system". They also relate decentralization to fishers' participation in the management of fisheries resources. They argue that, "Decentralization is a bridge to increase the participation of local communities and local people in fisheries management" (Satria and Matsuda, 2004b).

Since the start of the era of reform in 1998, Indonesia has experienced many fundamental changes. One of these is the change from a centralized, authoritarian regime to a decentralized and more democratic form of government. Not only politics, fisheries management has also been decentralized.

Decentralization of fisheries management is stated explicitly in Article 18 of Law 32/2004 on Local Government. Article 18 (1) in essence states that "A local government that has marine territory is given the authority to manage resources in that marine territory". This authority extends to:

a) exploration, exploitation, conservation, and management of the marine resources,

b) administrative management,

c) spatial management,

d) enforcement of local and national regulations,

e) participation in maintenance of security, and

f) participation in defending national sovereignty

The law also specifies the limits to the authority of national and local government authority in managing marine and fisheries resources. Under this law, provincial government has the authority to manage marine territories up to 12 miles offshore, while district government manages one third of the provincial marine territory. National government has authority over marine territories of 12 miles offshore and beyond. However, under the Law $23 / 2014$ on Local Government, the authority to manage marine territories is only given to the provincial government. The district government has no authority anymore.

But has decentralisation improved the living conditions of fishers? This is the main focus of this paper. I argue that decentralisation of marine and fisheries resource management itself has had no significant impact on their living conditions. However, decentralization has opened up spaces for fishers to articulate their interests more openly and confidently. I also argue that decentralization has promoted social movement among fishers.

According to McAdam and Snow, the concept of social movement includes five aspects: collective or joint action, change-oriented goals, some degree of organisation, some degree of temporal continuity, and some extra-institutional collective action, or at least a mixture of extra-institutional (protesting in the streets) and institutional (political lobbying) activity (McAdam and Snow, 1997:xviii). Further, McAdam and Snow (1997) regard political opportunities as an important "conditions of conduciveness" which promote development of social movement. Before McAdam and Snow developed their theory of social movement, Dahrendorf presented a similar argument in his conflict theory. According to Dahrendorf (1963), there are three conditions of organisation to transform "unorganised quasi-groups" into "organised interest groups". One of these is the "political conditions of organization" (Dahrendorf, 1963: 186). According to Dahrendorf, a totalitarian system of government is an example of a social situation in which the political conditions for the formation of conflict groups are not met. Dahrendorf stated that:

"The totalitarian state is probably the most unambiguous illustration of a social situation in which these conditions are not fulfilled, and in which therefore at least oppositional interest groups cannot emerge despite the presence of quasi-groups and latent interests. Where a plurality of conflicting parties is not permitted and their emergence suppressed by the absence of freedom of coalition and by police force, conflict groups cannot organize themselves even if all other conditions of their organization are present"(Dahrendorf, 1963:186).

Although Indonesia under Suharto was authoritarian, not a totalitarian system, the political conditions were very similar in many ways. For example, there was no freedom of speech including through demonstration, 
opposition was oppressed, and so on. Unlike the centralised and authoritarian government system of the New Order, in era of reformation and decentralisation, space for various local interest groups, including fishers, to articulate their interests has been opened wide.

With regard to fisheries, David L. Howell (1995) noted the importance of the role played by the state in effecting social change in Japanese fisheries. Howell argued that "...the state is a key variable in understanding how changes in social and economic relations evolved" (Howell, 1995:180). Similarly, Fairley (1990) argued that fishery class formation is affected by the state. Thus, it is expected that political autonomy and decentralisation of fishery management in Indonesia would facilitate fishers' social movement.

For the purpose of this research, data on fisher poverty are sourced mainly from the research conducted in Indramayu and Garut in 2010, while research in Balikpapan, which was conducted in 2006 for my dissertation, is the main source for the description of the social structure and struggle of the fishers (Note 2). Data were collected using qualitative and quantitative techniques. Qualitative data were collected mainly from interviews and observations, while surveys were used to collect most of the quantitative data. In Indramayu and Garut the surveys had 60 respondents each, while in Balikpapan a simpler survey was conducted with 201 respondents. Respondents were selected using convenience sampling (Singleton, Jr. et al, 1988: 153) which takes into account type of fishing gear, size (scale) of fishing unit as well as status of fishers (boat owner or labourer). Secondary data were also collected from relevant sources such as government reports and documents.

The research was conducted in three locations: Balikpapan, Indramayu, and Garut. Balikpapan is a municipality located in the eastern part of the province of East Kalimantan. It is situated in a coastal area facing the Sulawesi Straits. As the ward with the largest fisher population in this province, Manggar was selected as a research location. Indramayu is a district in West Java province. It is situated on the northern coast of the island of Java, directly facing the Java Sea. Two villages there, Eretan Wetan and Eretan Kulon, are well known as fishing villages. These two villages were chosen as the research site in Indramayu. Garut is also a district in West Java, but situated in the southern part of the island of Java. In this district, two villages, Pamalayan and Mancagahar, were selected as the research site. These two villages are situated on the coast, directly facing the Indian Ocean.

Most fishers in these three locations are small-scale fishers. In Balikpapan, for example, most fishers use gill nets, mini trawls, and traps from small boats with outboard motors. In Indramayu, the administrative sub district where Eretan Wetan and Eretan Kulon are situated, out of 1,117 fishing boats, 908 units were less than 6 GT, 74 units were 6-10 GT, 31 units with inboard motors were 10-30 GT, and 4 units with inboard motors were more than 30 GT. In one of the main fish landing harbours situated in Pamalayan, Garut, 36 non powered boats, 299 outboard motor boats, and 22 inboard motor boats were recorded.

\section{Fishers' Living Conditions}

If decentralization is a key to improving fishers' living conditions, and if decentralization in general and decentralization of fishery management in particular have been implemented successfully, the living conditions of fishers would be expected to have improved during the era of decentralization. However, this research shows that many fishers are still poor and bound to their patrons. Fishers too perceive that their living conditions have not improved since decentralization.

\subsection{Income and Poverty}

It is important to note at the outset that fisher incomes vary greatly according to type of fishing gear, size of fishing boat and level of technology used, fishing ground, and season. The incomes of small- and medium-scale fishers are uncertain even within a given season, let alone between seasons. To make matters even more complicated, several small-scale fishers in Garut say that the seasons have changed and are more unpredictable than before.

In terms of seasons, fishers in Indonesia are well versed in the so-called peak seasons and off seasons in their locale. In Balikpapan, for example, the off season lasts from around July to September or even October. In Garut, January to April is the off season, and peak season is only around three months, from August to October. In general peak seasons and off seasons last only around three months a year, respectively. The remaining six months are called transitional periods; three months transition from the off season to peak season, and three months from the peak season to the off season.

The off season is marked by severe weather, such as heavy rain, strong winds, and large, high waves. Fish are scarce during this season, too. Fishers seldom put out to sea during this season, those who do operate very close to the shore and only when the weather is relatively fair. The off season is a difficult time financially for the fishers. Many are forced to sell their possessions such as TV, radios, or anything of value, in order to survive. 
Many borrow money from middlemen, thereby intensifying this exploitative patron-client relationship.

Some fishers overcome their economic difficulties by "doing something else" or undertaking secondary employment. Unfortunately, data indicate that not many fishers in Indramayu and Garut have secondary employment. In Indramayu, for example, $96.7 \%$ of our respondents work solely as fishers and have no other job, while in Garut the figure is a lower 71.7\%. Some fishers, especially in Garut, also work as farmers or labourers.

Reflecting this situation, the household income of fishers in Indramayu and Garut, varies widely, IDR 120,000 to IDR 15.9 million per month, with an average of IDR 1,419,333.33 per month. The average household income of fishers in Indramayu is higher, at IDR 1,766,500/month compared with IDR 1,072,167.00/month in Garut (see Table 1).

Two factors contribute to this difference. First, the size of fishing boat and type of technology used; and second, ecological factors. In Indramayu, fishing boats tend to be larger and the technology used more advanced than in Garut. This allows fishers from Eretan Wetan in Indramayu to operate in distant fish fishing grounds, such as Sumatera, Lampung, Bangka, and Kalimantan. In addition, fishers in Garut operate in the Indian Ocean, which generally has bigger waves, thereby limiting the fishing grounds available to small-scale fishers such those from Pamalayan and Mancagahar villages.

Data indicate that the heads of households (the fishers) contribute the larger proportion of household income. In Indramayu, for example, husbands contribute $72.2 \%$ of the household income, compared with $81.1 \%$ in Garut. However, the figures also show that many wives and children make an important contribution to the household income. Table 1 compares the contributions of husband, wife, and children to the household income as a whole.

Table 1. Sources of household income of fishers in Indramayu and Garut, 2010 (IDR/month)

\begin{tabular}{cccc}
\hline Source of Income & Indramayu & Garut & Total \\
\hline Husband & $1,159,667(72.2 \%)$ & $857,000(81.1 \%)$ & $1,008,333(76.6 \%)$ \\
Wife & $428,500(20.9 \%)$ & $124,333(12.1 \%)$ & $276,417(16.6 \%)$ \\
Children & $111,667(5.7 \%)$ & $90,833(6.7 \%)$ & $101,250(6.2 \%)$ \\
"Donation" & $66,667(1.2 \%)$ & $0(0.0 \%)$ & $33,333(0.6 \%)$ \\
Total & $1,766,500(100 \%)$ & $1,072,167(100 \%)$ & $1,419,333(100 \%)$ \\
\hline
\end{tabular}

Source: primary data

Each year, through the Central Bureau of Statistics (BPS), the Indonesian government establishes rural and urban poverty lines. In 2010, the rural poverty line was IDR 192,354/month per capita, and the urban poverty line, IDR $232,989 /$ month per capita. People with a monthly income below the poverty line are categorised as poor. This means that almost half the fishers in Indramayu and Garut (42.5\%) fall within the poor category (see Table 2). It is interesting to note that the percentage of poor fishers in Garut (51.7\%) is higher than that in Indramayu (33.3\%). In keeping with these figures, the average per capita income of fisher households in Indramayu is also higher than in Garut, at IDR 429,405 and IDR 272,065, respectively.

It is also important to emphasize that the range of monthly per capita income is very wide, from a low of IDR 30,000 (well below the poverty line) to a high of IDR 3,975,000.00 (well above the poverty line). This gap between rich and poor among fishers is remarkable. In general, the better off fishers are those who own larger fishing boats that employ more advance technology.

Table 2. Distribution of fishers by poverty category, 2010

\begin{tabular}{|c|c|c|c|}
\hline Category & Indramayu & Garut & Total \\
\hline Poor & $20(33.3 \%)$ & $31(51.7 \%)$ & $51(42.5 \%)$ \\
\hline Not poor & $40(66.7 \%)$ & $29(48.3 \%)$ & $69(57.5 \%)$ \\
\hline
\end{tabular}

Source: primary data 


\subsection{Exploitation and Hegemony}

One of the striking features of the social structure of fishing communities in Indonesia is the patron-client relationships that exist between boat owners and crew, and between moneylenders and boat owners (particularly small-scale fishers). The patron is known by such terms as bakul, juragan, and punggawa. In the three study sites, most of the small-scale fishers - both boat owners and crew - are bound to patrons.

The patrons provide 'assistance' to their clients, such as loans for day to day expenses, medical bills, trips home, or wedding ceremonies. Patron-client relationships between boat owners and crew are developed partly because income from the sea is very uncertain. During the off season, crew members often have to ask the boat owner for financial assistance. As one punggawa in Balikpapan said, "...the fishers usually come to us for help". Boat owners are generally willing to provide their crew financial assistance because they need labour.

The patron-client relationship between moneylenders and boat owners is often initiated by an absence or lack of capital to acquire a fishing boat and fishing gear. In this situation, the fisher borrows from a moneylender to purchase the equipment, such as a boat, engine, and fishing gear, needed to start a fishing business. The moneylender also covers the costs of for their daily activities at sea. If fishers have damage to their engines, nets, boats, floating nets, and so forth, it is the punggawa who provides the money for the repairs. For example, one fisher said, "If I don't go to sea for three days, the punggawa will come and ask me why I haven't been out fishing. If I explain that the engine of my boat is damaged, he'll pay for the repairs or buy a new engine for me".

However, all the 'assistance' that the patrons provide is not without consequences. All the financial assistance given is counted as debt, and as long as a fisher is unable to pay this debt, he is bound to the moneylender. "All of us are bound to punggawa ... Our hands are tied ... If your debts aren't paid up, you can't get away from the punggawa," said a fisherman in Balikpapan. Naturally, the larger the debt, the more difficult it is to pay off, and many fishers take their debts to their graves. A fisher in Balikpapan may be in debt to IDR 40 million, depending on the type of fishing gear he uses. In Eretan, Indramayu, local traditional fishermen typically owe between two and four million rupiahs to moneylenders. The majority are unable to settle their debts, which are then passed on to future generations.

Usually, the money lenders know their 'members' or clients well. As one punggawa in Balikpapan said: "We know our members: some are productive, some mediocre, some less productive". He went on to explain that members have different personalities, and therefore need to be handled in different ways: "... some need to be threatened, others handled with courtesy". Members who make mistakes can be blacklisted by the punggawa, making it difficult for them to get work, even with other punggawa.

Another consequence of this patron-client relationship is that the fishers have to sell the fish they catch to their patrons. In Balikpapan, patrons (moneylenders) employ two mechanisms to take advantage of this relationship: by setting prices, and charging a percentage. Typically, patron buys at a price that is significantly lower than the market price. For example, in Balikpapan, punggawa set prices at anything between IDR 500 and IDR 3,000 per kilogramme below the market price. Meanwhile, in Eretan, Indramayu, the price differential can be up to half of the market price. In addition, the punggawa in Balikpapan take a fee of $5 \%-10 \%$ of total sales. Operating costs and other debts are also deducted, the amount depending on the volume of the fisher's catch as well as the temperament of the punggawa. If the total catch is small, and the punggawa is lenient, little or no deduction will be made. If a Balikpapan-based fisher wants to sell his catch in another location, such as Java or Sulawesi, he has to report and provide sales slips to his punggawa in Balikpapan.

Based on Wright's (1987) definition of exploitation, the relationship between the punggawa and fisher clearly contains an element of exploitation. The punggawa appropriates the fisher's products, among others by suppressing prices and charging a percentage. In addition, the welfare of the punggawa depends very much on the work of his 'members'. A saying common among young fishers translates loosely as, "The wealthy punggawa live carefree, happy lives on the crushed and broken bones of the fishers".

Despite this, most fishers view the punggawa in a positive light. One prominent fisher, for example, is proud to have been loyal to his punggawa: "Thank God, I have never changed my punggawa. Changing punggawa causes nothing but problems". Another fisher agreed, saying: "You shouldn't make a habit of changing punggawa". The same fisher added that it was normal if the punggawa set fish prices at IDR 3,000/kg below the market price because they provide fishers zero-interest working capital loans. The attitude of a senior fisher in Markoni, Balikpapan, is even more remarkable. Since the death of his original punggawa, H.C, his punggawa has been H, son of the late H.C. He has remained faithful H, in remembrance of his late father's services. "From when I first started out with a small outboard motor, through a TS Yanmar and Mitsubishi, and now a Jiang Dong 300, H.C assisted me. I told his son that even though his father had died, his name lived on in my heart." According to this 
fisher, others who had been with H.C had complained about how his son runs the business, and had thought about changing punggawa: "But, I calmed them down. I told them to remember what his father had done for us. I told them that he's still learning and that we should help him."

Even if they feel that they have enough capital, fishers still need the punggawa. "Without the punggawa, who would buy our fish?" said one. "What would happen to our fish?" A leading fisher emphasised the problems that arise from changing one's punggawa: "Fishers who are always changing their punggawa, will have problems selling their fish. And if no one buys your fish, you won't have any income".

This section describes the domination of fisher by moneylenders in this patron-client relationship. If decentralization of fishery management is successful, it should free fishers from this exploitative, hegemonic relationship, and lead to an improvement in their living conditions in general. But how do fishers themselves feel about decentralisation?

\subsection{Fishers and Decentralization}

Overall, fishers do not have a positive perception of decentralisation. This comes as no surprise because, as described above, decentralisation has not brought any significant improvement to their living conditions. Tragically, most fishers feel that not only have their living and environmental conditions deteriorated during this era of decentralisation, they get less attention from government as well. As Table 3 shows, 53.3 percent of respondents said that their welfare had deteriorated since autonomy. Also, the majority of respondents (53.4\%) felt that local government had paid them less attention since autonomy.

As described earlier, many blame centralisation for the depletion of fishery resources and therefore advocate decentralisation as a means to replenish fishery resources. However, this study found that 95 percent of respondents in Indramayu and Garut believed that fishery resources had deteriorated even more since autonomy. Likewise, the state of the fishing grounds and environment had also deteriorated, according to 50 percent of the respondents (Table 3). Thus, this study shows that ten years on, decentralisation's 'promise' of improvement in fishery resource management has yet to be realised.

Table 3. Fishers' opinions of decentralization

\begin{tabular}{llcccc}
\hline & & \multicolumn{4}{c}{ Condition after Autonomy } \\
\cline { 3 - 6 } No & \multicolumn{1}{c}{ Issues } & Better & Same & Worse & Total \\
\hline 1 & Fishers' Welfare & $23(19.2 \%)$ & $33(27.5 \%)$ & $64(53.3 \%)$ & $120(100.0 \%)$ \\
2 & Local government attention & $19(15.8 \%)$ & $37(30.8 \%)$ & $64(53.4 \%)$ & $120(100.0 \%)$ \\
3 & Fishery resources & $3(2.5 \%)$ & $3(2.5 \%)$ & $114(95.0 \%)$ & $120(100.0 \%)$ \\
4 & Fishing grounds & $15(12.5 \%)$ & $45(37.5 \%)$ & $60(50.0 \%)$ & $120(100.0 \%)$ \\
5 & Environment & $3(2.7 \%)$ & $45(41.7 \%)$ & $60(55.6 \%)$ & $108(100.0 \%)$ \\
\hline
\end{tabular}

Source: primary data

\subsection{The Fishers' Movement}

In terms of fishers' movement, decentralisation has brought some important advances. Since decentralisation, fishers have become more active, open, and confident about voicing their interests. Decentralisation has even promoted a social movement among fishers.

In Garut, a fisher's organisation called Rukun Nelayan was established in 2005 and is now being chaired by a new board for the period of 2010-2015. Today there are 11 of these groups in the village in this study, each group comprising fishers that use the same fishing gear. However, these fisher groups not been very active in pursuing their interests. One of the functions of the groups is to coordinate the fishers, so whenever the government distributes aid, it can be distributed equally. As the chair of Rukun Nelayan explained:

"...one of the objectives of the Rukun Nelayan is to coordinate aid, such as rice aid. I record all the data of the fishers here. At the moment there are 11 groups in this village. The fishers in each group use the same fishing gear."

This rice aid was provided by Garut district government to the fishers in 2010 and 2011 as part of a famine relief program. The aid was distributed to the fishers because they had suffered a prolonged bad dry season and an 
earthquake in 2009. The relief aid was donated after the fisher's leaders submitted proposals to the district government with the assistant of local fisheries office. Each family got $10 \mathrm{~kg}$ of rice. This was the first time the fishers had made proposals for aid to local government.

Another first in their struggle is holding demonstrations at local government offices. On 1 January 2010, fishers from Pamalayan village, Garut, joined in a demonstration outside the sub district government offices demanding the disbursement of disaster relief funds. As a consequence, in early January 2010 all disaster relief funds were released to the public, including the fishers. Although this demonstration is not directly related to the exploitative relationship between fishers and punggawa, it is certainly a new way in which the fishers are struggling to achieve their goals in this era of decentralisation.

In Eretan, Indramayu, a fishers' organization called Serikat Nelayan Tradisional (SNT) was established in 2003, with its headquarters in Indramayu city. The Eretan chapter has participated in SNT rallies demanding compensation for the losses resulting from environmental pollution caused by the state oil company, Pertamina. They have held many demonstrations because, according to the SNT Eretan chair, requests made through official channels were ignored. Finally in 2010, Pertamina provided 'grants' amounting to IDR 2,000,000 per fisher plus five fishing nets.

In Balikpapan, East Kalimantan, small-and medium-scale fishers are more active in defending their interests. Their organisations were also more powerful and solid than those in Garut and Indramayu. In Balikpapan, a collective and organised fisher movement first began in late 1999, about a year after the fall of President Suharto. This collective movement was triggered by frequent collisions between the fishers' boats and fishing gear and large vessels, such as company-owned pontoons, which crossed the territorial waters of Balikpapan. Such collisions are, of course, very detrimental to the fishers, because they directly threaten their livelihood and endanger their lives.

To address this problem, several fisher leaders held a meeting with the regional people's representative assembly (Riva'i, 2006). During the meeting they also agreed to call on the Balikpapan mayor to respect the wishes of the majority of local fishers and issue a decree legalising the use of stationary lift nets in Balikpapan waters.

The fishers called their struggle group Amanat Aliansi Masyarakat Nelayan (AAMN). To make the issue known to the wider public, information about the proposed meeting with the regional assembly was also given to the local press. Representatives of these fishers finally met with the regional assembly on 11 November 1999.

With no solution resulting from the meeting with the regional assembly, on 11 April 2000 as many as 150 fishers representing AAMN again met with the regional assembly. When this second meeting proved unfruitful, the fishers took matters into their own hands: on 20 April, they 'hijacked' three ships that were sailing through their fishing ground. After holding them 'hostage' for three days, the vessels were returned, but the fishers held on to the ships' documents. So the fishers returned to regional assembly for the third time. This meeting was more intense, with all the special commissions of the regional assembly in attendance, along with external agencies, including the local fisheries office, port administrator (Adpel), water and air police (Polairud), and Balikpapan local government's deputy head of legal affairs, and the owners of the pontoons.

The third meeting resulted in a very important decision; one that fishers in Balikpapan had been fighting for. It was agreed that the companies involved would compensate the fishers whose boats were involved in collisions with the pontoons. In addition, Decree of the East Kalimantan District Head No. 75/1973, which prohibits the use of stationary lift nets, was revoked by the Balikpapan mayor, who subsequently issued a decree (No. 188/2000) legalising the use of stationary lift nets in Balikpapan waters.

As a result of the action taken by these fishers, their movement became widely known among, and supported by, fishers in Balikpapan. The scope of their struggle also expanded to cover wider issues: it was no longer only about damaged boats and fishing gear. One of the young fisher leaders who were active in these struggles, Ruslan Riva'i, explained: "Investigations into collisions triggered a strengthening of the local community's influence over economic, environmental and budget policies; policies that had a bearing on the lives of the fishers." (Riva'i, 2006:142).

Fishers' struggles in Balikpapan have triggered their collective action and the subsequent establishment of their organizations. As mentioned above, in their earlier struggle, fishers agreed to name their organisation Amanat Aliansi Masyarakat Nelayan (AAMN), and in December 2000 they inaugurated their group under this name, which was later changed to Aliansi Masyarakat Nelayan (AMaN or AMN). AMN activists have organised and led several demonstrations, and engaged in dialogue and negotiation, to fight for the interests of fishers in Balikpapan. 
The AMN charter describes the organisation as a 'forum for fishers and fishing communities in East Kalimantan', and its aim as 'achieving a decent standard of living, justice, and physical and spiritual well-being for fishers/fishing communities in East Kalimantan'. AMN subsequently got funding support from UNDP to promote women's economic activities as well as provide scholarships for fishers' children. In addition, AMN received funding support from USAID, among others, to publish the periodic newsletter "Fishers' Voice".

A new fishers' organization formed recently, on the initiative of former AMN activist Ruslan Riva'i, is Serikat Nelayan Balikpapan (SNB). The SNB charter describes the objective of the organisation as 'enabling SNB members to fight for their rights as citizens, including social, economic, political, and environmental rights', while the goal of the SNB is to 'enhance the position and bargaining power of fishers to secure their rights as citizens'.

Several mining companies operating in Balikpapan have also threatened fishers' livelihoods. One of these is the multinational mining company, Theiss. The battle between small-scale fishers who fish using mini purse seine nets (dogol in Indonesian) and Thiess was related to the company's construction of a port behind its offices in Balikpapan. Construction of the port between June 2004 and April 2005 involved the dredging of the seabed along the route to and from the port. This loss and damage to fishing grounds and fishing gear, in particular for those fishers who use mini purse seine nets. Left marginalised by these activities, small-scale fishers in Balikpapan fought to get compensation from Thiess.

To strengthen their position, the fishers formed an organization called Forum Nelayan Bersama Korban Thiess (FNBKT). Their prolonged fight against Thiess took various forms. Initially, they had meetings with Thiess and other parties on many occasions. For example, on 4 March 2005, they organized a meeting with the Thiess, Balikpapan's deputy mayor, members of the regional assembly, chief of police, military commander, and sub district heads.

Seven months later, no agreement had been reached, and on 20 June 2005 about 300 fishers held a demonstration outside the Theiss offices, demanding compensation of IDR 1 billion for the loss of fishing grounds and damage to their fishing gear caused by the activities of Thiess (see Figure 1). After the demonstration, the fishers managed to secure a meeting with Thiess, with the deputy mayor, chief of police, East Balikpapan sub district head, Manggar village head, and some members of Balikpapan regional assembly in attendance.

In follow-up to the demonstration, on 21 June 2005, another meeting was held at the office of mayor. Attending this meeting were the deputy mayor, members of the regional assembly, the East and South Balikpapan chiefs of police, the head of the marine and fisheries office, and others. However, by 2006, the fishers had still to receive any compensation. Then, on 12 February 2006 the fishers sent a letter to Theiss through AMN inquiring about the status of their demands. Thiess responded through a letter dated 30 May 2006, informing the fishers that their allegations against the company were not proven, and therefore Thiess was under no obligation to pay them compensation. According Thiess, settlement of this matter had been mediate by the deputy mayor. The last the author heard of the matter was that the fishers finally received compensation from Theiss, amounting to IDR 200 million or IDR $1-1.5$ million for each fisher (Note 3).

Another multinational mining company that threatened the livelihoods and lives of the fishers in Balikpapan was Unocal. This happened when Unocal conducted seismic activities in the fishing grounds of fishers who use fish aggregating devices (FADs) known in Indonesian as rumpon (Note 4). A part of Unocal's oil exploration operations, these seismic activities took place from 15 June to 22 July 2004 (Tribun Kaltim, 10/27/2004). While conducting these activities, Unocal cut FADs belonging to several fishers, triggering the conflict between the fishers and Unocal.

The fishers' fight to obtain compensation from the Unocal for the damage to their fishing gear was a tough and long process. The fishers held meetings and demonstrations many times. For example, on 28 September 2004, a joint meeting was held between the regional assembly, representatives of Unocal and the fishers in the regional assembly offices. Then on 28 December 2004, hundreds of fishers held a demonstration outside the Unocal offices. Meanwhile, on the same day, Serikat Nelayan Balikpapan (SNB) -another fishers' organization - also organized a protest, blocking and 'hijacking' vessels used for seismic activity.

Both the total number of fishers who should get compensation and the amount of compensation per fisher were matters for negotiation and debate. Initially, Unocal agreed to compensate only fourteen fishers, despite the fishers arguing that forty-one were entitled to compensation. Since then, the number fishers for whom compensation was being claimed increased from forty-one to sixty, to sixty-eight, and finally to seventy-two.

Fishers in Balikpapan have been marginalised not only by private companies, but also by government policies.. 
One government policy that was detrimental to fishers was the increase in fuel prices in October 2005. "Talking about the impact of fuel price increase was enough to make us cry", said one fisher, adding "A rope has an end, but there is no end in sight to the problems this fuel price increase has caused us."

As diesel prices increased, the fishers' operating costs spiralled, resulting in reduced incomes and, in some cases, even losses. "If I used diesel, I wouldn't make any money at all," said a fisher. To cope with the rising diesel prices, small-scale fishers in Balikpapan switched from diesel to kerosene, which was almost half the price, at IDR 2,600/litre compared with IDR 4,300/litre for diesel. Although well aware of the damage to their engines that using kerosene would cause, they had no choice if they were to survive.

Unfortunately, this was not the end of the fuel problems for small-scale fishers in Balikpapan. Because the supply of kerosene in Balikpapan was limited, fishers were often unable to get hold of any and could not go out to fish. The irony is that East Kalimantan is one of Indonesia's major oil-producing provinces.

Not only was kerosene in short supply, the situation was exacerbated further by government policies regarding the consumption of subsidised kerosene. During this time the fishers purchased the subsidized kerosene to use as fuel for their fishing boats. However, according to Presidential Decree 9/2006, fishing was not on the list of activities for which the use of subsidized fuel was permitted. Therefore, even if the East Kalimantan provincial government had attempted to assist the fishers by asking for additional supplies of kerosene, the state oil company Pertamina would not have approved the request. This ignited the anger of small-scale fishers in Balikpapan. "It was actually the government that was the cause our hardship," said one fisher who attended a meeting on 29 September 2004 to discuss their struggle to get kerosene. Another fisher said:

"There was no kerosene available. The fishers of Manggar had raised their voices, waited patiently, and then exploded. What should the government have done? The situation got worse after the election of the new president. The government really was walking a fine line creating this crisis. Ants may be small, but when provoked they will unite. You can't blame ordinary people for what they might do as a result..."

Endless kerosene shortages in 2006 brought another prolonged battle for the fishers in Balikpapan. They repeatedly visited the regional assembly and the municipality. On 13 and 17 May 2006, the fishers called meetings with the Mayor to discuss the kerosene shortages. On 20 and 24 July 2006, fisher leaders went to the regional assembly to pass on their demands. On 26 July 2006, another joint meeting was held at the regional assembly, attended by municipal government officials, the municipal industry and cooperatives agency, the Association of Indonesian Oil \& Gas Entrepreneurs, and Pertamina Balikpapan's marketing division. However, kerosene remained in short supply, and on 13 September 2006, the fishers demonstrated outside the Pertamina offices in Balikpapan, and then outside the office of the mayor.

In response, the municipal government immediately called a meeting that evening. After the meeting, a fisher activist received information that, in accordance with Presidential Regulation 9/2006 on the use of the subsidised kerosene, the fishers would not be getting any kerosene. Upon receiving this news, he contacted the police threatening to hold another demonstration and torch-lit rally to the Pertamina oil tanker port. Taking this threat seriously, on the morning of 15 September, the chief of police and his officers went to the fishers' compound in Manggar to negotiate with the fishers. The chief of police apparently contacted Pertamina to get approval of the fishers' request for kerosene. In the end, the fishers got an extra supply of kerosene from Pertamina, although unofficially due to the government policy limiting the uses of subsidised kerosene. To ensure the continued supply of kerosene in the future, the fishers formed a task force on 20 September 2006. However, as long as the government policy regarding subsidized kerosene remains unchanged, supplies of kerosene for the fishers will continue to be unpredictable.

Another interesting aspect of the struggle of the fishers in Balikpapan is their use of the mass media. Several AMN leaders wrote articles for publication in local newspapers such as the Kaltim Post, Tribun Kaltim, and Post Metro Balikpapan. They also have good relationships with, and often interviewed by, journalists from those newspapers. The former chair of AMN and founder of SNB (Riva'i) maintained his close relationship with these journalists. For example, at the height of the kerosene crisis in 2006, he phoned several reporters to convey the fishers' threat to unite and occupy the Pertamina offices in Balikpapan. Post Metro Balikpapan headlined the story ("Nelayan Siap Duduki UPms VI" - "Fishers Prepare to Occupy Pertamina Offices") the same day (6 September 2006, p13). In another example of the close relationship between the fishers and the press, on the evening of 12 September, the day before the fishers' demonstration outside the Pertamina offices, a Tribun Kaltim journalist contacted Riva'i. The following day, the story of the planned demonstration was published under the title, "Hari Ini Nelayan Demo Krisis Minyak Tanah" or "Today Fishers Demonstrate Against Kerosene Shortages" (Tribun Kaltim, 13/09/2006, p 11). 
Local newspapers have also played an important role in promoting the Balikpapan fishers' struggles. Their 1999 fight against the pontoon owners was widely publicised by journalists from local newspapers. Likewise, their battles with Thiess and Unocal, and their fight to get kerosene, were reported intensively. Examples of these news reports are shown in Figure 3.

Fishers in Balikpapan are also actively involved in local politics. Of the 100 fishers interviewed for this study, 33\% are members of a political party, and $58.4 \%$ of the 101 owner fishers interviewed are members of a political party. Senior fishers and AMN activists are regularly invited by local government to attend meetings such as development planning meetings. The fishers in Balikpapan have been quite influential in this era of decentralisation, which has got them the attention of politicians and local government authorities.

In 2006, AMN devised a new, political strategy to fight for fishers' interests. In the run up to the election of the mayor and deputy mayor of Balikpapan for the period 2006-2011, AMN asked the candidates to sign social and political contracts that AMN had drafted. The contract contained a ten-point pledge to improve the lives of fishers in Balikpapan, which promised, among others to "facilitate and resolve issues facing fishers in Balikpapan, the issue of pollution/coastal and marine environments", and "allocate a budget for subsidised fuel for fishers".

\section{Concluding Remarks}

Theoretically, decentralization in general and of fishery management in particular, has opened up opportunities for local government to significantly improve the living conditions of local fishers. For example, local government can develop and strengthen fisher cooperatives, which can then provide the fishers services, such as credit, social safety net, and basic necessities. This would, in turn, strengthen the fishers' negotiating position with middlemen. Schemes to encourage small-scale fishers to expand and become medium- and large-scale operations could also be developed by local government. Development of fisheries infrastructure such as cold storage, ice factories, and water supply could help improve the incomes of fishers. Local government could introduce mandatory fish auctions, which would mean the fishers getting higher prices for their catch. Successful local fisheries development would improve the incomes of fishers and their social relations, and, with the use of improved technologies, increase their production capacity.

Unfortunately, this study indicates that decentralization in Indonesia, including decentralization of fishery resources management as laid down in Law 22/1999 and subsequently in Law 32/2004, has not brought any significant improvement to fishers' living conditions. A very high proportion of small-scale fishers and workers are still living in poverty. The livelihoods of fishers remain vulnerable to attack from natural phenomenon, corporate activities and government policies. Within the social system itself, small-scale fishers and workers are still a dominated and exploited class. More than a decade since its implementation, decentralization of fisheries management can only be described as a broken promise. Turner and Podger's argument that it is too early to judge the effects of regional autonomy on poverty alleviation is no longer valid (Turner and Podger, 2003:142).

This comes as no surprise, since decentralization of fisheries management in the study sites has not been followed up by development of any new local fishery management systems. Local government in the three study sites has not issued any regulations to protect fisheries or small-scale fishers and workers or to improve their incomes. Nor has any legislation has been made to manage fishery resources sustainably. This confirms the findings of studies conducted by Masyhuri Imron et al. (2008 and 2009). Thus, I argue that what is important is not the decentralization per se, but those who are in power. If the people in power put more emphasize in pursuing economic growth and their own prosperity without paying enough attention to the environment and poor people, decentralization would not bring any significant improvement to the environment and poor people such as fishers. In that case, decentarlization simply moves the locus of power from central government to local government.

However, decentralization has facilitated the development of new tactics in the fight for the interests of fishers in the three study sites, which McAdam and Snow (1997) concluded constituted a social movement. This social movement is an integral part of the socio-political development that has taken place in Indonesia since the end of the New Order era, which is one of democratisation and decentralisation. This study demonstrates that decentralisation can be perceived as what McAdam and Snow (1997) call "the conditions of conduciveness" or what Dahrendorf (1963) calls "the political conditions of organization" that provide "political opportunities" for the development of social movement among fishers.

Fishers' organizations identified in this study are all well established and have been actively fighting in the fishers' interests since the end of the New Order. During the Soeharto administration it would have been almost impossible for the fishers to hold demonstrations outside the offices of parliament and mayor, or the offices of 
large corporations, either national (such as Pertamina) or multinational (such as Thiess and Unocal). Likewise, to 'hijack' ships and threaten to blow up the Pertamina tankers would have been unthinkable during the New Order. Therefore, I agree with those who argue that "Decentralization has opened up the possibility for grass-roots participation in the local political context, direct political participation, and the lobbying of the local leaders" (Sulistiyanto and Erb, 2009:4).

However, I argue that the main reason for the success of the social movements of the fishers in the three study sites was that they were defending their immediate short-terms interests, such as getting compensation and assistance from the local government. More fundamental issues, however, have yet to be addressed, including pro small-scale fisher public policy, social security, improved arrangement of fishing zones, and even establishment of "communal property rights" over fishing grounds like in Japan. In Japan, as Ruddle (1987) explains, "No conceptual distinctions exist between land holdings, or land tenure, and sea holdings, or sea tenure. And as is unambiguously set forth in the Civic Code, fisheries enjoy a legal status equal to that of land ownership". I think establishment of "communal property rights" like this is very important for small-scale fishers in Indonesia, and therefore worth fighting for. As Cordell said, "sea tenure issues are at the core of fishermen's livelihoods. They are worth fighting over either on the water or in court" (in Bavinck, 2001: 24). To establish such a tenure system is arguably beyond the scope of decentralization. However, effectively implemented decentralization could contribute significantly to that goal of fisheries development.

\section{Acknowledgement}

As stated earlier, this paper is written based on two separate studies. One was conducted for my dissertation and the other one as a part of the competitive national strategies research program of the Directorate General of Higher Education (DGHE), Republic of Indonesia. I would like to thank the DGHE for providing the fund for conducting this researh.

\section{References}

Bailey, C. (1988). The Political Economy of Marine Fisheries Development in Indonesia. Indonesia No. 46 (Oct). Cornell Southeast Asia Program. https://doi.org/10.2307/3351043

Bavinck, M. (2001). Marine Resource Management. Conflict and Regulation in the Fisheries of the Coromandel Coast. Sage Publication, New Delhi/Thousand Oaks/London.

Betke, F. (1988). Prospect of a "Blue Revolution" in Indonesian Fisheries: A Bureaucratic Dream or Grim Reality? (Unpublished doctoral dissertation). Bielefeld University, Germany.

Dahrendorf, R. (1963). Class and Class Conflict in Industrial Society. Stanford University Press, Stanford, California.

Dewan Hankamnas dan BPP Teknologi. (1996). Benua Maritim Indonesia.

Fairley, B. (1990). The Crisis, the State and Class Formation in the Newfoundland Fishery. In Fairley, Bryant, Colin Leys, \& James Sacouman (Eds.), Restructuring and Resistance: Perspectives from Atlantic Canada. Garamond, Toronto.

Friedmann, J. (1998). Empowerment. The Politics of Alternative Development. Blackwell, Cambridge MA \& Oxford UK.

Howell, D. L. (1995). Capitalism from Within: Economy, Society, and the State in a Japanese Fishery. University of California Press, Berkeley, Los Angeles, London.

Imron, M. (Ed.). (2008). Manajemen Sumberdaya Laut dalam Perspektif Otonomi Daerah. Respon Daerah Terhadap Kebijakan Otonomi di Sektor Kelautan. LIPI, Jakarta.

Imron, M. et al. (2009). Kebijakan Pengelolaan Sumberdaya Laut di Era Otonomi Daerah: Respons Daerah Terhadap Kompleksitas Permasalahan Kenelayanan. Paper presented at the Final Research Seminar at Pusat Penelitian Kemasyarakatan dan Kebudayaan (PMB-LIPI), 23-25 November 2009.

Kinseng, R. A. (2007). Kelas dan Kelas Konflik pada Kaum Nelayan di Indonesia (Studi Kasus di Balikpapan, Kalimantan Timur). (Unpublished doctoral dissertation).Department of Sociology, Faculty of Sociology and Philosophy, University of Indonesia.

McAdam, D., \& Snow, D. A. (1997). Social Movement. Roxbury Publishing Company, Los Angeles, California, USA.

Ministry of Marine Affairs and Fisheries. (2009). Marine Affairs and Fisheries in Figures 
Neis, B. (1981, Spring). Competitive Merchants and Class Struggle in Newfoundland. Studies in Political Economy, (5), 127-143. https://doi.org/10.1080/19187033.1981.11675712

Pelras, C. (2006). Manusia Bugis. Nalar, Jakarta.

Riva'i, R. (2006). Menggugat Penabrak di Laut. Nelayan Balikpapan Membangun Gerakan in M. Imran Amin et al (eds.), 2006. Meninggalkan Titik Nol. Nelayan Melawan Perlakukan Buruk. Jaring Pela \& CBCRM-RC.

Ruddle, K. (1987). Administration and Conflict Management in Japanese Coastal Fisheries. FAO Fish. Teck.Pap., (273), p 93.

Satria, A., \& Matsuda, Y. (2004a). Decentralization of Fisheries Management in Indonesia. Marine Policy, 28, 437-450. https://doi.org/10.1016/j.marpol.2003.11.001

Satria, A., \& Matsuda, Y. (2004b). Decentralization Policy: An Opportunity for Strengthening Fisheries Management System? Journal of Environment and Development, 13(2),179-196. https://doi.org/10.1177/1070496504264969

Singleton, Jr., R. et al. (1988). Approaches to Social Research. Oxford University Press, New York, Oxford, USA.

Sulistiyanto, P., \& Erb, M. (2009). Indonesia and the Quest for "Democracy". In M. Erb, \& P. Sulistiyono (Eds.), Deepening Democracy in Indonesia? Direct Elections for Local Leaders (Pilkada). Institute of Southeast Asian Studies, Singapore.

Turner, M., \& Podger, O. (2003). Decentralization in Indonesia. Redesigning the State. Asia Pacific Press at the Australian National University, Canberra, Australia.

\section{Notes}

Note 1. This figure is for marine capture fisheries only, and does not include inland capture fisheries.

Note 2. Although this paper is written based on the research in these years, based on the latest information that I know, it is argued that the argument and conclusion of this paper is still valid up to now.

Note 3. Personal text message communication with an activist in Balikpapan, 8 June 2011.

Note 4. The local name for these fishers is pejala.

\section{Copyrights}

Copyright for this article is retained by the author(s), with first publication rights granted to the journal.

This is an open-access article distributed under the terms and conditions of the Creative Commons Attribution license (http://creativecommons.org/licenses/by/4.0/). 